\title{
A Rare Case of Vault Angiofibroma
}

\author{
R. Jayanthi' ${ }^{1}$, Iysverya G.T.2. Nishanthi Chandru ${ }^{3}$
}

1, 2, 3 Department of Obstetrics and Gynaecology, Meenakshi Medical College and Hospital, Chennai, Tamilnadu, India.

\section{PRESENTATION OF CASE}

A 52-year-old female patient, para 2 live 2, who attained surgical menopause 10 years back, presented to the outpatient department (OPD) with complaints of white discharge per vagina for 6 months, which was watery in consistency and was not associated with foul smell or itching vulva. She had history of hysterectomy done for fibroid uterus 10 years back. On examination, she was afebrile and vital signs were within normal limits. Per abdomen examination, was normal, while, per speculum examination revealed a watery discharge per vaginum. The per vaginal examination revealed a firm, non-tender, globular mass felt arising from the vaginal vault and the mass did not bleed on touch.

A globular mass of size $3 \times 4 \mathrm{cms}$, pinkish white in colour, was seen occupying the whole of the vaginal vault with curdy white precipitates in the vaginal rugosities as well as over the mass.

\section{CLINICAL DIAGNOSIS}

Cellular angiofibroma (CA) belongs to soft tissue tumours that predominantly occur in the distal genital tract of both genders: vulvo vaginal region in women and inguinoscrotal area in men.1,2

Ultrasonography (USG) pelvis revealed post hysterectomy status and left adnexal mass of (5.3 x 2.3) cms was noted. Magnetic resonance imaging (MRI) of abdomen \& pelvis revealed a post hysterectomy status and a well-defined heterogeneous signal intensity lesion of ( $40 \times 34 \times 37) \mathrm{mm}$ was seen in the vaginal vault? / cause? / recurrence.

\section{DIFFERENTIAL DIAGNOSIS}

- Spindle cell lipoma

- Solitary fibrous tumour

- Angiomyofibroblastoma

- Aggressive angiomyxoma
Corresponding Author: Dr. Nishanthi Chandru,

Department of Obstetrics and Gynaecology, Meenakshi Medical College and Hospital, Chennai, Tamilnadu, India.

E-mail:drnishanthichandru@gmail.com

DOI: $10.14260 / \mathrm{jemds} / 2021 / 250$

How to Cite This Article: Jayanthi R, Iysverya GT, Chandru N. A rare case of vault angiofibroma.J Evolution Med Dent Sci 2021;10(16):1177-1178, DOI: $10.14260 /$ jemds $/ 2021 / 250$

Submission 05-09-2020,

Peer Review 18-02-2021, Acceptance 25-02-2021, Published 19-04-2021.

Copyright (C) 2021 R. Jayanthi et al. This is an open access article distributed under Creative Commons Attribution License [Attribution 4.0 International (CC BY 4.0)] 


\section{PATHOLOGICAL DISCUSSION}

Histopathological examination of the tissue sample sent intra operatively showed benign neoplasm, composed of proliferation of spindle cells and blood vessels, s / o angiofibroma.

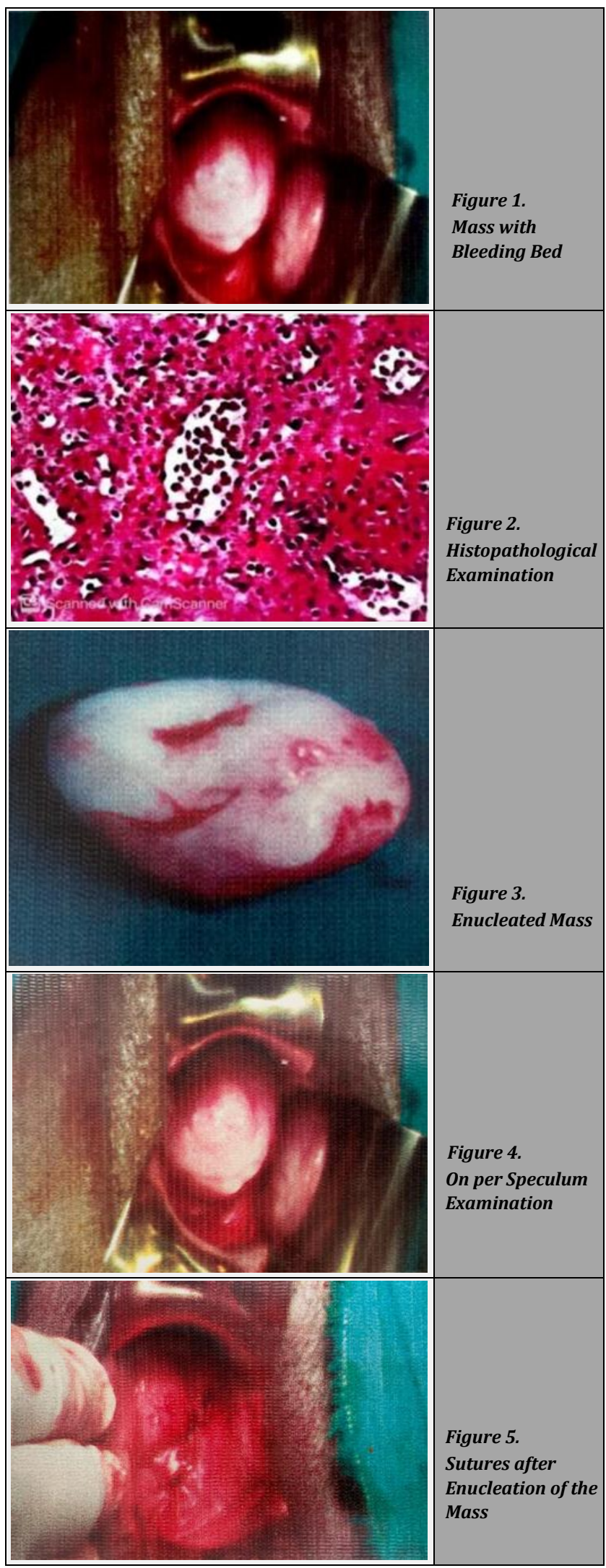

DISCUSSION OF MANAGEMENT

On per speculum examination, vault mass of $3 \times 4 \mathrm{cms}$ was visualised. After analysing clinical and radiological findings, consent was obtained from the patient, examination under anaesthesia (EUA) and excision of the mass was done. Intraoperatively well circumscribed, encapsulated mass was seen appearing from left lateral side of the vault. The mass was enucleated and delivered in toto, and bleeding bed was sutured with interrupted sutures and haemostasis was achieved.

\section{DISCUSSION}

Cellular angiofibroma is a benign mesenchymal lesion occurring mainly in superficial soft tissue of the genital region. The first description of this tumour dates from Nucci et al. article in 1997. It typically arises in women of late reproductive age, mostly during the fifth decade of life. ${ }^{3}$

Patient is usually asymptomatic. The treatment requires a simple local excision with a rim of uninvolved tissue. There is extremely low ability for recurrence as per literature.

Financial or other competing interests: None.

Disclosure forms provided by the authors are available with the full text of this article at jemds.com.

\section{REFERENCES}

[1] Nucci MR, Granter SR, Fletcher CD. Cellular angiofibroma: a benign neoplasm distinct from angiomyofibroblastoma and spindle cell lipoma. Am J Surg Pathol 1997;21(6):63644.

[2] Laskin WB, Fetsch JF, Mostofi FK. Angiomyofibroblastoma-like tumor of the male genital tract: analysis of 11 cases with comparison to female angiomyofibroblastoma and spindle cell lipoma. Am J Surg Pathol 1998;22(1):6-16.

[3] McCluggage WG, Perenyei M, Irwin ST. Recurrent cellular angiofibroma of the vulva. J Clin Pathol 2002;55(6):4779. 